UDC 631.348 .45

Original research paper

doi:10.5937/AASer1845027D

Acta Agriculturae Serbica, Vol. XXIII, 45 (2018); 27-36

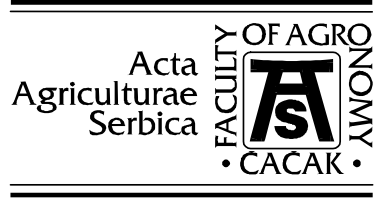

\title{
Performance testing of field crop sprayers in the Rasina District
}

\author{
Dragoslav Đokić ${ }^{1}$, Rade Stanisavljević ${ }^{2}$, Jordan Marković ${ }^{1}$, Jasmina \\ Milenković ${ }^{1}$, Dragan Terzić ${ }^{1}$, Tanja Vasić ${ }^{1}$, Saša Barać ${ }^{3}$ \\ ${ }^{1}$ Institute for Forage Crops, 37251 Globoder-Kruševac bb, Republic of Serbia \\ ${ }^{2}$ Institute for Plant Protection and Environment, 11000 Beograd, Teodora \\ Drajzera 9, Republic of Serbia \\ ${ }^{3}$ University of Priština, Faculty of Agriculture, 38219 Lešak, Kopaonička bb, \\ Lešak, Republic of Serbia \\ Corresponding author: dragoslav.djokic@ikbks.com
}

\begin{abstract}
In agricultural production, pests and diseases of agricultural crops, as well as weed plants, cause significant losses in the yield and quality of agricultural products. One of the most effective ways of fighting is the use of a wide range of chemicals called pesticides. In accordance with the EU Directives 2009/128/EC and 2006/42/EC underlying the standard EN 13790, the Plant Protection Administration of the Ministry of Agriculture and the Environment of the Republic of Serbia has established a framework for the control of sprayers and mist blowers. Maintaining sprayers for pesticide application in a good state of repair and proper working order reduces their harmful effects on human health and the environment. The nozzle is one of the most important parts of plant protection machines, responsible for the following major functions: delivery of a given amount of liquid in a unit of time, dispersion of the liquid by making droplets of different sizes and forming a stream of a particular shape. Testing of the working safety of sprayers and nozzles was carried out in accordance with the European Standard EN 13790 which specifies the methods and equipment for inspection. The flow rate of nozzles was measured by an S001 nozzle tester (AAMS-Salvarani, Belgium). The measuring equipment used for testing the pesticide application device can accurately determine any deviation and irregularity in the application.
\end{abstract}

Keywords: measuring equipment, sprayers, pesticides, nozzles, plant protection. 


\section{Introduction}

In agricultural production, all agricultural crops are susceptible to harmful effects of plant diseases, pests and weed plants. For the control of harmful organisms, the most effective way for preventive protection against diseases, and for controlling pests and weeds is the chemical way. Contemporary agricultural production implies increasing use of pesticides as plant protection products, as well as the use of pesticide application machines (Urošević, 2001). The application of pesticides by sprayers is the most commonly used pesticide application process for crop protection because it is a cheap, effective and fast method (Višacki et al., 2014b). The massive use of plant protection machines for the application of chemicals or pesticides has a major impact on the environment. High and careless use of pesticides can cause long-term adverse effects on soil fertility and quality. The basic task of mechanized protection to be fulfilled by tractor sprayers is to provide a uniform vertical distribution of the working fluid with precise dosing in individual zones for environmental reasons (Bugarin et al., 2008). The performance of application machines treatment depends on proper functioning, adjustment and design, which affect the accuracy of pesticide distribution, the accuracy of dosage and the size of losses (Bugarin et al., 2010; Srivastava, 2014). Inappropriate use of pesticides can cause harmful effects on operator, animals and the environment (Sedlar et al., 2008; Sedlar et al., 2014). The uniformity of spraying is affected by the method of disintegration of the working fluid. Distribution uniformity is described by the percentage coefficient of variation and is very important for the quality and efficiency of plant protection against diseases and pests as well as desiccation (Višacki et al., 2014a). In plant protection, emphasis should be placed on the use of modern machines that provide controlled application of pesticides (Nikolić et al., 2009).

Testing of plant protection machines in the European Union began in the late 1990s. In Germany, testing has shown that most defects in sprayers are caused by defective nozzles (Tadić et al., 2014). In EU countries, regulations on the compulsory inspection of plant protection machines (with the 2009/128/EC and 2006/42/EC guidelines) have been established as the basis of standard EN 13790 (Banaj et al., 2014; Đokić et al., 2015; Đokić et al., 2016; Barać et al., 2017). The adopted laws comply with EU 91/414 EEC and relate to the mandatory control of sprayers and mist blowers (Koprivica et al., 2015). The most important factors for plant protection machines are nozzles, which perform major functions such as delivery of a given amount of liquid in a unit of time. Nozzles disperse the liquid by creating droplets of an appropriate size, forming a stream of an appropriate shape (Banaj et al., 2010; Bajkin et al., 2014). Effective crop protection is possible only if uniform distribution of the working fluid on the treated surface, that is, the quality of pesticide application, is ensured. Richards et al. (1997) emphasized that the preferred coefficient of variation of the flow rate of nozzles is less than $10 \%$, and is acceptable up to $15 \%$. Wang et al. (1995) 
found that nozzles are in relatively good operation if the coefficient of variation is less than $10 \%$ to $12 \%$. According to the criteria set by Višacki et al. (2013), if the coefficient of variation is less than $7 \%$, the working fluid distribution uniformity is exceptional. If this value is higher, ranging from $7 \%$ to $9 \%$, uniformity is satisfactory. The coefficient of variation is tolerable up to $11 \%$; if it is higher, the uniformity of distribution is considered insufficient.

The aim of this study was to test sprayers and measure the flow of working fluid in several types of sprayers in order to determine their proper functioning, flow rate accuracy and flow uniformity of nozzles.

\section{Material and methods}

A field sprayer trial was conducted with farmers in the Rasina District in central Serbia. During the test, a control test for the proper functioning of nozzles was carried out, involving flow measurements and flow uniformity examination. Nozzle flow was measured by an SOO1 nozzle tester (AAMS-Salvarani, Belgium). The testing of five sprayers from different manufacturers (A, B, C, D, E) was done in three repetitions. The test pressure was 3 bars; the rpm PTO for tractors was $540 \mathrm{~min}^{-1}$. Sprayer type A is manufactured by "Agromehanika", Kranj. The pump capacity of this sprayer is $601 \mathrm{~min}^{-1}$, and the volume of the liquid reservoir is 4001 . The B-type sprayer is a 400 liter rear mounted sprayer manufactured by "Fischer", Switzerland. Sprayers types C and E are manufactured by "Morava" Požarevac, tank capacity 3301 . Sprayer type D is made by "Agromehanika" Kranj, with a pump capacity of $601 \mathrm{~min}^{-1}$, and a 3301 liquid reservoir. The number of nozzles differed depending on the type and spray width of sprayer. It ranged from 16 nozzles (sprayers C, D, E), 19 nozzles (sprayer A), to 22 nozzles (sprayer B). The results were subjected to the analysis of the coefficient of variation. The technical specifications of the tested sprayers are shown in Table 1.

Table 1. Technical specifications of the tested sprayers

\begin{tabular}{lccccc}
\hline \multirow{2}{*}{ Parameters } & \multicolumn{5}{c}{ Type of sprayers } \\
\cline { 2 - 5 } & $\mathrm{A}$ & $\mathrm{B}$ & $\mathrm{C}$ & $\mathrm{D}$ & $\mathrm{E}$ \\
\hline Volume of tank (1) & 400 & 400 & 330 & 330 & 330 \\
Max. rpm PTO $\left(\mathrm{min}^{-1}\right)$ & 540 & 540 & 540 & 540 & 540 \\
Required tractor power & $>30$ & $>30$ & $>30$ & $>30$ & $>30$ \\
$(\mathrm{~kW})$ & & & Rear mounted sprayer & 16 & 16 \\
Aggregation mode & 19 & 22 & 16 & 3 & 3 \\
Number of nozzles & 3 & 3 & 3 & $80-110$ & $80-110$ \\
Work pressure (bar) & $80-110$ & $80-110$ & $80-110$ & & \\
Treatment angle $\left({ }^{\circ}\right)$ & & & & & \\
\hline
\end{tabular}




\section{Results and discussion}

The results of testing the average flow rate of sprayers are shown in Table 2.

Table 2. The flow rate of crop sprayers

\begin{tabular}{|c|c|c|c|c|c|}
\hline \multirow{3}{*}{$\begin{array}{l}\text { Number of } \\
\text { nozzles }\end{array}$} & \multicolumn{5}{|c|}{ Flow rate of crop sprayers $\left(1 \mathrm{~min}^{-1}\right)$} \\
\hline & \multicolumn{5}{|c|}{ Type of sprayers } \\
\hline & $\mathrm{A}$ & $\mathrm{B}$ & $\mathrm{C}$ & $\mathrm{D}$ & $\mathrm{E}$ \\
\hline 1. & 0.719 & 0.988 & 0.795 & 0.738 & 0.525 \\
\hline 2. & 1.118 & 1.003 & 1.055 & 0.742 & 1.349 \\
\hline 3. & 0.970 & 0.973 & 0.835 & 0.742 & 1.559 \\
\hline 4. & 1.058 & 0.978 & 1.007 & 0.746 & 1.472 \\
\hline 5. & 1.410 & 0.795 & 1.142 & 0.785 & 1.350 \\
\hline 6. & 1.304 & 0.887 & 1.022 & 1.108 & 1.575 \\
\hline 7. & 1.447 & 1.017 & 1.116 & 0.819 & 1.206 \\
\hline 8. & 1.337 & 0.799 & 1.225 & 0.844 & 1.584 \\
\hline 9. & 1.602 & 1.320 & 1.044 & 0.801 & 1.726 \\
\hline 10. & 1.451 & 1.243 & 0.824 & 0.812 & 1.573 \\
\hline 11. & 1.497 & 1.246 & 1.128 & 0.958 & 1.505 \\
\hline 12. & 1.418 & 1.214 & 0.916 & 0.586 & 1.492 \\
\hline 13. & 1.400 & 0.882 & 1.144 & 0.787 & 1.495 \\
\hline 14. & 1.747 & 0.946 & 1.142 & 0.760 & 1.586 \\
\hline 15. & 1.533 & 0.947 & 1.146 & 0.664 & 1.723 \\
\hline 16. & 1.599 & 0.905 & 1.174 & 0.712 & 0.422 \\
\hline 17. & 0.958 & 0.976 & - & - & - \\
\hline 18. & 1.379 & 0.862 & - & - & - \\
\hline 19. & 1.358 & 0.932 & - & - & - \\
\hline 20. & - & 0.883 & - & - & - \\
\hline 21. & - & 1.241 & - & - & - \\
\hline 22. & - & 1.062 & - & - & - \\
\hline Average & 1.332 & 1.005 & 1.045 & 0.788 & 1.384 \\
\hline CV (\%) & 19.39 & 15.25 & 12.94 & 14.93 & 27.42 \\
\hline
\end{tabular}

The results showed that the average flow rate of sprayers ranged from 0.7881 $\min ^{-1}$ (sprayer D) to $1.3841 \mathrm{~min}^{-1}$ (sprayer E). The average flow rate of sprayers $\mathrm{A}, \mathrm{B}$ and $\mathrm{C}$ was $1.3321 \mathrm{~min}^{-1}, 1.051 \mathrm{~min}^{-1}$ and $1.0451 \mathrm{~min}^{-1}$, respectively. The coefficient of variation ranged from $12.94 \%$ for Sprayer C to $27.42 \%$ for sprayer E. Barać et al. (2017) reported that the average nozzle flow rate was $0.9541 \mathrm{~min}^{-1}, 1.1691 \mathrm{~min}^{-1}$ and $1.1901 \mathrm{~min}^{-1}$ (type C), with the coefficient of variation in the range of $12.24 \%$ to $29.49 \%$.

The average nozzle flow rates of the tested sprayers are shown in Graphs 1-5. For Sprayer A, the minimum average working fluid flow rate was $0.7191 \mathrm{~min}^{-1}$ for nozzle 1 , and the maximum rate of flow was $1.7471 \mathrm{~min}^{-1}$ for nozzle 14 . The average flow rate for sprayer A was $1.3321 \mathrm{~min}^{-1}$ (Graph 1). 
Graphic 1. Flow rate of crop sprayers $\left(1 \mathrm{~min}^{-1}\right)$ sprayer type A

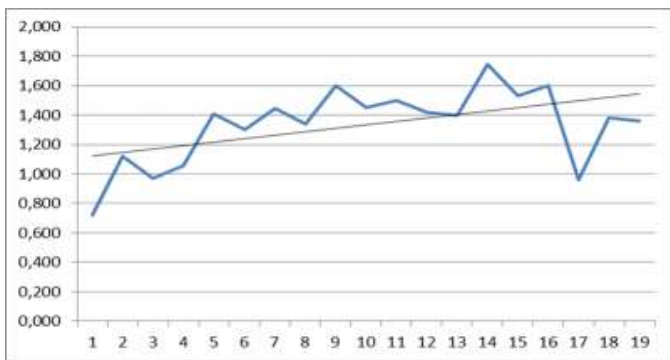

In sprayer $\mathrm{B}$, the average flow rate ranged from $0.7951 \mathrm{~min}^{-1}$ for nozzle 5 to $1.3201 \mathrm{~min}^{-1}$ for nozzle 9. The average flow rate was $1.0051 \mathrm{~min}^{-1}$ (Graph 2).

Graphic 2. Flow rate of crop sprayers $\left(1 \mathrm{~min}^{-1}\right)$ sprayer type B

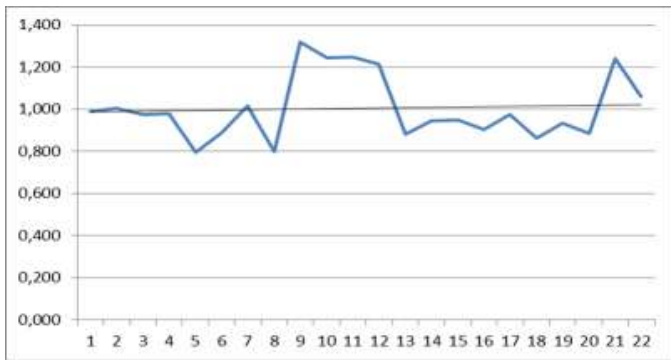

Sprayer C had a flow rate of $0.7951 \mathrm{~min}^{-1}$ for nozzle 1 and $1.2251 \mathrm{~min}^{-1}$ for nozzle 8. The average flow rate was $1.0451 \mathrm{~min}^{-1}$ (Graph 3).

Graphic 3. Flow rate of crop sprayers $\left(1 \mathrm{~min}^{-1}\right)$ sprayer type $\mathrm{C}$

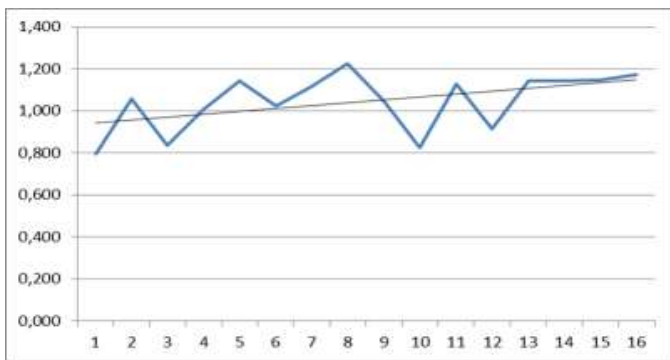


Sprayer D had a minimum flow rate of $0.5861 \mathrm{~min}^{-1}$ for nozzle 12, and a maximum of $1.1081 \mathrm{~min}^{-1}$ for nozzle 6 . The average flow rate was $0.7881 \mathrm{~min}^{-1}$ (Graph 4).

Graphic 4. Flow rate of crop sprayers $\left(1 \mathrm{~min}^{-1}\right)$ sprayer type D

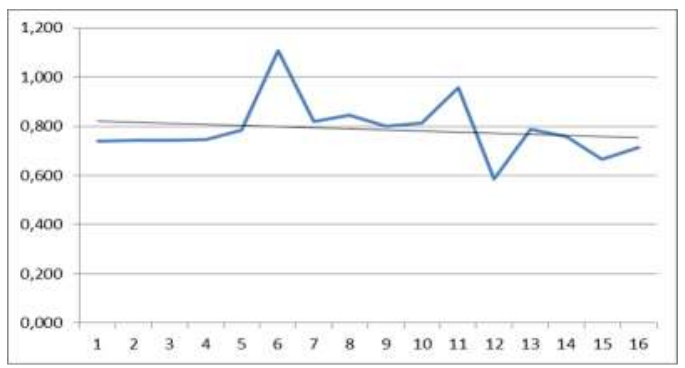

The flow rate of sprayer $\mathrm{E}$ ranged from $0.4221 \mathrm{~min}^{-1}$ for nozzle 16 to 1.7261 $\min ^{-1}$ for nozzle 9 . The average flow rate was $1.3841 \mathrm{~min}^{-1}$ (Graph 5).

Graphic 5. Flow rate of crop sprayers $\left(1 \mathrm{~min}^{-1}\right)$ sprayer type $\mathrm{E}$

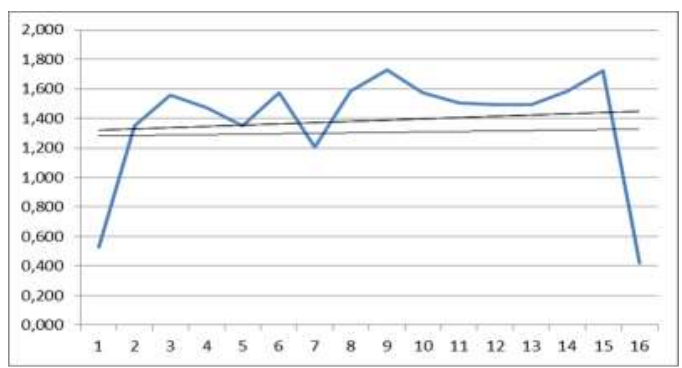

A comparative overview of the average flow rates of nozzles for all five sprayer types is given in Graph 6. The minimum average flow rate of $0.7881 \mathrm{~min}^{-}$ ${ }^{1}$ was for D-type sprayer and a maximum of $1.3841 \mathrm{~min}^{-1}$ for sprayer E. Sprayers $\mathrm{B}$ and $\mathrm{C}$ had uniform values of average flow rates of operating fluid of 1.0051 $\min ^{-1}$ and $1.0451 \mathrm{~min}^{-1}$, respectively the average flow rate of type A sprayer was $1.3321 \mathrm{~min}^{-1}$. 
Graphic 6. Flow rate of crop sprayers $\left(1 \mathrm{~min}^{-1}\right)$ sprayer types A, B, C, D, E

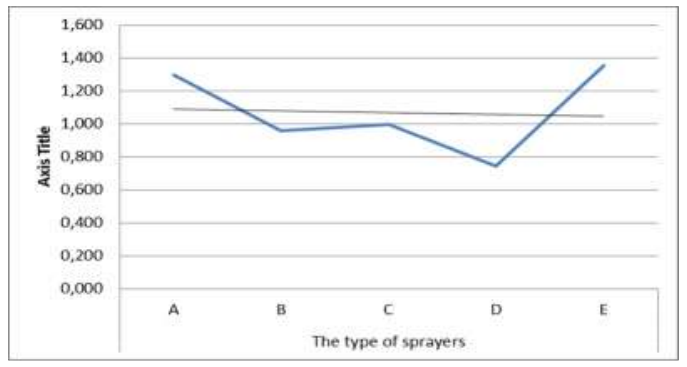

The tested sprayer nozzles should be replaced as none of them meets the criteria regarding the coefficient of variation for the flow rate of nozzles set by Wang et al. (1995) and Višacki et al. (2013). According to Richards et al. (1997), only sprayer $\mathrm{C}$ nozzles are acceptable for further application. When the deviation from the nominal flow rate is above the specified limits, the working fluid distribution is usually incorrect and uneven, most often due to the clogging and damage of nozzle holes.

\section{Conclusions}

Defective nozzles on field sprayers are the biggest problem for the proper operation of plant protection machines. In the field, nozzles are often clogged due to mechanical impurities, poor water quality or deterioration due to prolonged exploitation time, which significantly affects the quality of pesticide application. In addition to regular maintenance and cleaning, it is necessary to perform regular inspection of the proper operation of nozzles on field sprayers and mist blowers. The working fluid flow rate depends on nozzle condition; pump condition and sprayer maintenance method. The average flow rates of the tested sprayers ranged from a minimum of $0.7881 \mathrm{~min}^{-1}$ (sprayer D) to a maximum of $1.3841 \mathrm{~min}^{-1}$ for sprayer E. In sprayers A, B and C, the average operating fluid flow rate was $1.3321 \mathrm{~min}^{-1}, 1.0051 \mathrm{~min}^{-1}$ and $1.0451 \mathrm{~min}^{-1}$, respectively the coefficient of variation ranged from $12.94 \%$ (sprayer C) to $27.42 \%$ (sprayer E). Such a large deviation in the average values of the fluid flow rate is due to nozzle deterioration or blockage; therefore, they need to be cleaned and, if necessary, replaced with new ones.

\section{Acknowledgement}

The research in this paper is part of Project TR-31057, funded by the Ministry of Education, Science and Technological Development of the Republic of Serbia. 


\section{References}

Bajkin A., Ponjičan O., Sedlar A., Zoranović M., Turan J. (2014): Ekološki i energetski parametri primene poljoprivredne mehanizacije. Poljoprivredni fakultet, Novi Sad, Srbija.

Banaj Đ., Tadić V., Banaj Ž., Menđušić I., Duvnjak V. (2010): Ispitivanje ujednačenosti površinske raspodjele tekućine ratarskih prskalica. 44. hrvatski i 4. međunarodni simpozijum agronoma, Opatija, Hrvatska: 897 - 901.

Banaj Đ., Tadić V., Petrović D., Knežević D., Banaj A. (2014): Vertikalna raspodjela zračne struje raspršivača AGP 200 ENU. Zbornik radova 42. međunarodnog simpozijuma iz područja mehanizacije poljoprivrede. Aktualni zadaci mehanizacije poljoprivrede. Sveučilište u Zagrebu, Agronomski fakultet, Zavod za mehanizaciju poljoprivrede, Zagreb, Hrvatska: 167 - 177.

Barać S., Petrović D., Vuković A., Biberdžić M., Đikić A., Đokić D. (2017): Rezultati ispitivanja ratarskih prskalica u uslovima centralne Srbije. Savremena poljoprivredna tehnika, 43 (1): 17-26.

Bugarin R., Đukić N., Sedlar A. (2008): Činioci efikasne aplikacije u zaštiti višegodišnjih zasada orošivačima. Savremena poljoprivredna tehnika, Novi Sad, Srbija, 34 (3-4): 236-243.

Bugarin R., Đukić N., Sedlar A. (2010): Uticaj tehnike za aplikaciju pesticida na zagađenje zemljišta. Savremena poljoprivredna tehnika, Novi Sad, Srbija, 36, (2): 107- 116.

Đokić D., Vasić T., Milenković J., Terzić D., Stanisavljević R., Barać S., Koprivica R. (2015): The system of regular technical device control for the application of pesticides in the Republic of Serbia. Book of Proceedings, Sixth International Scientific Agricultural Symposium, Jahorina, Bosnia and Herzegovina: 930-935.

Đokić D., Marković J., Milenković J., Terzić D., Stanisavljević R., Barać S., Koprivica R. (2016): Application of measuring techniques in testing machines for the protection of plants in the Republic of Serbia. Book of proceedings, VII International Scientific Agriculture Symposium, Jahorina, Bosnia and Herzegovina: 1306-1311.

Koprivica R., Veljković B., Barać S., Đokić D. (2015): Značaj atestiranja uređaja za aplikaciju sredstava za zaštitu bilja. Zbornik naučnih radova, XX Savetovanje o biotehnologiji sa međunarodnim učešćem. Univerzitet u Kragujevcu, Agronomski fakultet, Čačak, 20 (22): 601-605.

Nikolić R., Malinović N., Bajkin A., Đukić N., Furman T., Brkić M., Janić T., Potkonjak V., Savin L., Tomić M., Ponjičan O., Simikić M., Bugarin R., Gligorić R., Sedlar A., Kostić M., Žigić N. (2009): Stanje i opremanje poljoprivrednom mehanizacijom u 2010. godini. Traktori i pogonske mašine, 14 (5): 7-22.

Sedlar A., Đukić N., Bugarin R. (2008): Savremena tehnička rešenja i mere poboljšanja efikasnosti orošivača u cilju primene malih i srednjih normi pri orošavanju voćnjaka. Savremena poljoprivredna tehnika, Novi Sad, Srbija, 34 (3-4): 117-128.

Sedlar A. Bugarin R., Đukić N. (2014): Tehnika aplikacije pesticida. Univerzitet u Novom Sadu, Poljoprivredni fakultet, Novi Sad, Srbija.

Srivastava M. (2014): Pesticides as pollutants of environment and use o botanicals as an alternate management strategy. Fifth International Scientific Agricultural Symposium "Agrosym 2014". Jahorina, Bosnia and Herzegovina: 473-477. 
Richards M. D., Hislop E. C., Western N. M. (1997): Static and dynamic patternation of hydraulic pressure nozzles. Aspects of Applied Biology, 48: 201 - 208.

Tadić V., Banaj Đ., Petrović D., Knežević D., Seletković N. (2014): Testiranje tehničkih sustava u zaštiti bilja u Republici Hrvatskoj. Zbornik radova 42. međunarodnog simpozijuma iz područja mehanizacije poljoprivrede, Aktualni zadaci mehanizacije poljoprivrede. Sveučilište u Zagrebu, Agronomski fakultet, Zavod za mehanizaciju poljoprivrede, Zagreb, Hrvatska: 161-166.

Urošević M. (2001): Mašine i aparati za primenu pesticida. Poljoprivredni fakultet Beograd, Institut za poljoprivrednu tehniku, Beograd, Srbija.

Višacki V., Sedlar A., Bugarin R., Turan J. (2013): Efekat radnog pritiska na uniformnost distribucije rasprskivača. Savremena poljoprivredna tehnika, 39 (2): 85-92.

Višacki V., Sedlar A., Turan J., Bugarin R., Burg P. (2014a): Ujednačenost aplikacije pesticida pri najčešćim parametrima eksploatacije. Savremena poljoprivredna tehnika, 40 (3): 125-134.

Višacki V., Sedlar A., Bugarin R., Turan J., Burg P. (2014b): Kvalitet aplikacije pesticida u kukuruzu i na strnjištu. Savremena poljoprivredna tehnika, 40 (3): 135-142.

Wang L. N., Zhang J.W., Slocombe, and D.K. Kuhlman. (1995). Spray distribution uniformity measurement using spectral analysis. In Pesticide Formulations and Applications: $13^{\text {th }}$ Vol., Am. Soc. for Testing and Materials. 


\title{
ISPITIVANJE KARAKTERISTIKA RATARSKIH PRSKALICA U RASINSKOM OKRUGU
}

\author{
Dragoslav Đokić ${ }^{1}$, Rade Stanisavljević ${ }^{2}$, Jordan Marković ${ }^{1}$, Jasmina \\ Milenković $^{1}$, Dragan Terzić ${ }^{1}$, Tanja Vasić ${ }^{1}$, Saša Barać ${ }^{3}$ \\ ${ }^{1}$ Institut za krmno bilje, 37251 Globoder-Kruševac bb, Republika Srbija \\ ${ }^{2}$ Institut za zaštitu bilja i životnu sredinu, 11000 Beograd, Teodora Drajzera 9, \\ Republika Srbija \\ ${ }^{3}$ Univerzitet u Prištini, Poljoprivredni fakultet, 38219 Lešak, Kopaonička bb, \\ Republika Srbija
}

\section{Rezime}

U poljoprivrednoj proizvodnji, štetočine i bolesti poljoprivrednih kultura, kao i korovske biljke svake godine prouzrokuju značajne gubitke u prinosu i kvalitetu poljoprivrednih proizvoda. Jedan od najefikasnijih načina borbe jeste primena brojnih i različitih hemijskih sredstava, koja se nazivaju opštim nazivom pesticidi. U skladu sa Direktivama Evropskog parlamenta 2009/128/EC i 2006/42/EC, kojima je osnova standard EN 13790, koji propisuje obavezni pregled mašina za zaštitu bilja, Uprava za zaštitu bilja Ministarstva poljoprivrede i životne sredine Republike Srbije uspostavlja okvir za kontrolu sistema prskalica i orošivača. Upotrebom tehnički ispravnih i kontrolisanih ratarskih prskalica za primenu pesticida smanjuje se njihov štetni uticaj na zdravlje ljudi i životnu okolinu. Jedan od najznačajnijih delova mašina za zaštitu bilja predstavljaju rasprskivači. Oni obavljaju najvažnije funkcije, kao što su: propuštaju zadate količine tečnosti $u$ jedinici vremena, raspršuju tečnost praveći kapljice odgovarajućih veličina i formiraju mlaz odgovarajućeg oblika. Testiranje radne ispravnosti prskalice i rasprskivača vršeno je u skladu sa evropskim normativom EN 13790, koji propisuje metode i opremu kojom se obavlja inspekcija. Protok rasprskivača je meren pomoću ispitivača pojedinačnih rasprskivača S001 belgijskog proizvođača "AAMS-Salvarani". Primenom merne opreme za ispitivanje ispravnosti rada uređaja za primenu pesticida, merenjem je moguće tačno ustanoviti svako odstupanje i nepravilnost $u$ radu. Dobijeni rezultati ukazuju na to da postoje značajna odstupanja ispitivanih parametara.

Ključne reči: merna oprema, prskalice, pesticidi, rasprskivači, zaštita bilja. 